\title{
Partially Shaded Operation of a Grid-Tied PV System
}

Conference Paper NREL/CP-520-46001 June 2009

\section{Preprint}

C. Deline

National Renewable Energy Laboratory

To be presented at the $34^{\text {th }}$ IEEE Photovoltaic Specialists Conference Philadelphia, Pennsylvania June 7-12, 2009

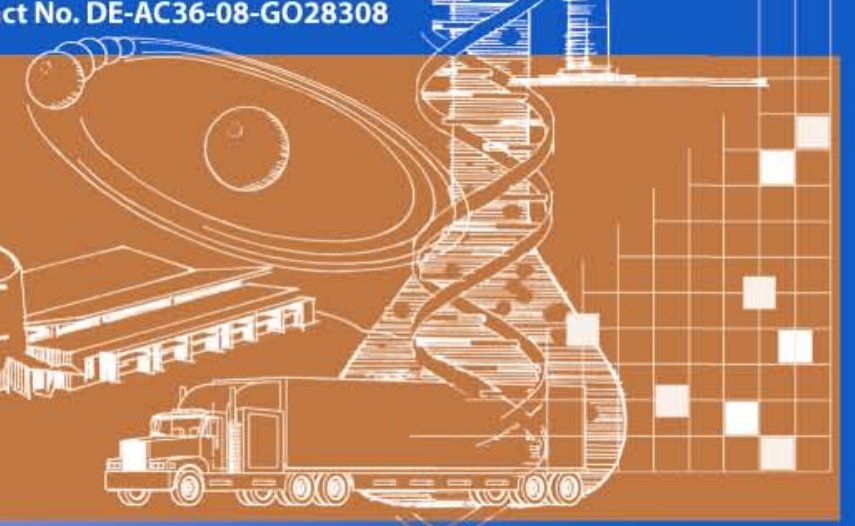




\section{NOTICE}

The submitted manuscript has been offered by an employee of the Alliance for Sustainable Energy, LLC (ASE), a contractor of the US Government under Contract No. DE-AC36-08-GO28308. Accordingly, the US Government and ASE retain a nonexclusive royalty-free license to publish or reproduce the published form of this contribution, or allow others to do so, for US Government purposes.

This report was prepared as an account of work sponsored by an agency of the United States government. Neither the United States government nor any agency thereof, nor any of their employees, makes any warranty, express or implied, or assumes any legal liability or responsibility for the accuracy, completeness, or usefulness of any information, apparatus, product, or process disclosed, or represents that its use would not infringe privately owned rights. Reference herein to any specific commercial product, process, or service by trade name, trademark, manufacturer, or otherwise does not necessarily constitute or imply its endorsement, recommendation, or favoring by the United States government or any agency thereof. The views and opinions of authors expressed herein do not necessarily state or reflect those of the United States government or any agency thereof.

Available electronically at http://www.osti.gov/bridge

Available for a processing fee to U.S. Department of Energy and its contractors, in paper, from:

U.S. Department of Energy

Office of Scientific and Technical Information

P.O. Box 62

Oak Ridge, TN 37831-0062

phone: 865.576 .8401

fax: 865.576 .5728

email: mailto:reports@adonis.osti.gov

Available for sale to the public, in paper, from:

U.S. Department of Commerce

National Technical Information Service

5285 Port Royal Road

Springfield, VA 22161

phone: 800.553.6847

fax: 703.605.6900

email: orders@ntis.fedworld.gov

online ordering: http://www.ntis.gov/ordering.htm 


\title{
PARTIALLY SHADED OPERATION OF A GRID-TIED PV SYSTEM
}

\author{
Chris Deline
}

National Renewable Energy Laboratory, Golden, CO

\begin{abstract}
Partial shading of a PV installation has a disproportionate impact on its power production. This paper presents background and experimental results from a single string grid-tied PV system, operated under a variety of shading conditions. In this configuration a shadow can represent a reduction in power over 30 times its physical size. Results are presented relating size and positions of shading to power reduction of the PV system. A simulation method is also described that provides an accurate description of shade based on a single site survey. This process can provide the basis for an accurate simulation of power reduction in a partially shaded $\mathrm{PV}$ system.
\end{abstract}

\section{INTRODUCTION}

There is continued interest among photovoltaic installers, regulators and owners to obtain accurate information on photovoltaic (PV) systems operating under shaded or mismatched conditions. It is best to avoid shade where possible; while partially shaded installations can still produce useful power for a portion of the day, shading will generally result in a significant reduction in power. [1] This is particularly true for building-integrated $P V$ which often requires the integration of modules with existing structures in sometimes crowded urban environments. [2] In the interest of expanding the number of $\mathrm{PV}$ installations worldwide and providing maximum benefit from these systems, it is useful to consider in more detail the power loss from partially shaded PV systems.

Regulatory agencies such as the California Energy Commission have a particular interest in obtaining information on shaded PV operation in order to accurately calculate rebate incentives for shaded systems. For incentive programs focused on installed capacity rather than actual kWh production, modeling the PV system and its access to the solar resource is required to obtain the expected performance of the system. Because shading of PV systems disproportionately reduces their power output, the rebate incentives need to be adjusted accordingly.

Prior experiments have been conducted investigating the effect of shade on various PV systems, many of which were cited in a comprehensive literature review by Woyte et al. [3] Other recent works include simulations of partially shaded PV cells [4,5], experimental results of different maximum power point tracking algorithms under shaded conditions [6] and the effect of shade on PV system performance $[7,8]$.

\section{SHADED MODULES}

Typically, a crystalline silicon module will contain bypass diodes to prevent damage from reverse bias on partially shaded cells. These diodes are placed across $12-18$ cells in what will be termed a 'group' of cells here. (Fig. 1) The bypass diode across this group of cells will begin conducting before the power dissipated into the shaded cell is enough to evolve damaging temperatures. [9,10] While the main purpose of a bypass diode is not necessarily to improve module performance under shaded conditions, this is a useful byproduct. The bypass diode allows current from non-shaded parts of the module to pass by the shaded part, and limits the effect of shading to only the neighboring group of cells protected by the same bypass diode. When a bypass diode begins conducting, the module voltage will drop by an amount corresponding to the sum of cell voltages protected by the bypass diode plus the diode forward voltage, but current from surrounding unshaded groups of cells continues around the group of shaded cells.

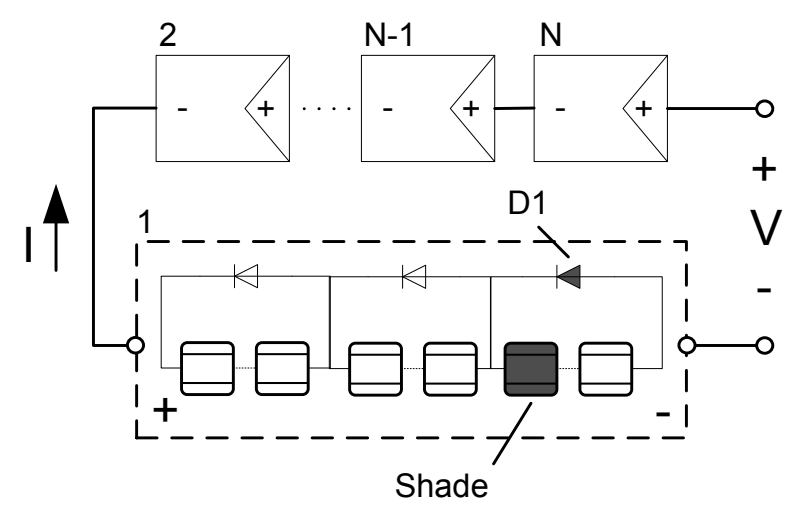

Fig. 1: $N$ modules are shown in series, each consisting of 3 groups of 18 cells. Each group of cells is connected to a bypass diode that begins conducting if shading causes a cell to go far enough into reverse bias. In this example, shade causes diode D1 to short out its group of cells, reducing module 1's voltage by $1 / 3$.

The effect of shade on power output of typical PV installations is nonlinear in that a small amount of shade on a portion of the array can cause a large reduction in output power. For instance, completely shading one cell of an array will cause the bypass diode protecting that cell to begin conducting, reducing the power of the module by 
as much as $1 / 3-1 / 2$ (depending on the number of groups of cells in the module). An ongoing experiment at the National Renewable Energy Laboratory (NREL) is designed to quantify the effects of shade on the performance of typical grid-tied PV installations.

\section{ARRAY CONFIGURATION AND RESULTS}

A 10-module series string of crystalline Si PV modules is mounted on the roof of NREL's Outdoor Test Facility at $180^{\circ}$ (South) azimuth and $40^{\circ}$ tilt. (Fig. 2) The $165 \mathrm{~W}$ modules are series-connected to an SMA $1800 \mathrm{U}$ grid-tied inverter which provides peak power tracking for the entire 10-module string. Each PV module consists of 3 groups of 18 cells, and each group of cells is protected by a bypass diode. The particular modules used in this experiment were from a prior experiment, comprised of two sets of five matched modules, each with a different antireflective top coating. There are some differences in power production of the modules due to different top coatings, but the effect was found to be negligible except for very early or late in the day when the data will not be considered anyway.

System performance and individual module voltages are tracked by current and voltage transducers connected to a Campbell Scientific datalogger. Additional plane-of-array (POA) irradiance is measured by Kipp \& Zonen and Li-Cor pyranometers. Heat tape wrapped around the Li-Cor pyranometer limits snow and ice buildup under wintry conditions. [11] A digital camera automatically records the extent of shade on the modules throughout the day, and thermocouples measure module temperatures.

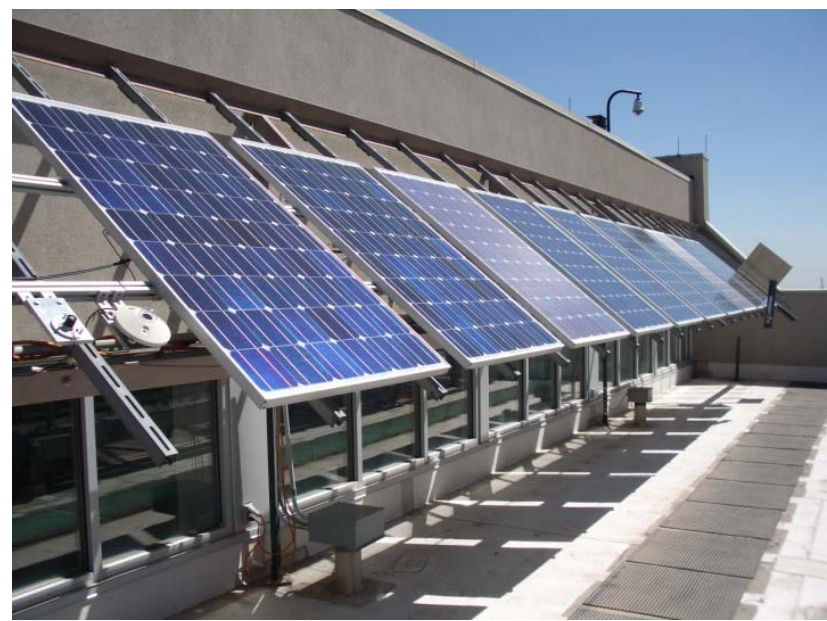

Fig. 2: Mounted solar modules and pyranometers. Shade obstructions for Test \#2 are visible at the far right.

\section{Test \#1: Direct shading of modules}

The single string array is peak-power tracked throughout the day by the grid-tied inverter. Individual module voltage is recorded along with the series string current. Partial shade is introduced onto several modules by applying opaque masking tape directly to the module. The impact of partial shading is determined by comparison of the shaded module's voltage with an unshaded 'control' module. Because current is continuous in this single string, a drop in module power is proportional to a drop in module voltage. Only a single group of cells in each module is shaded in this experiment, therefore module voltage will drop by up to $1 / 3$ as one of three bypass diodes begins conducting. (Fig. 3 )

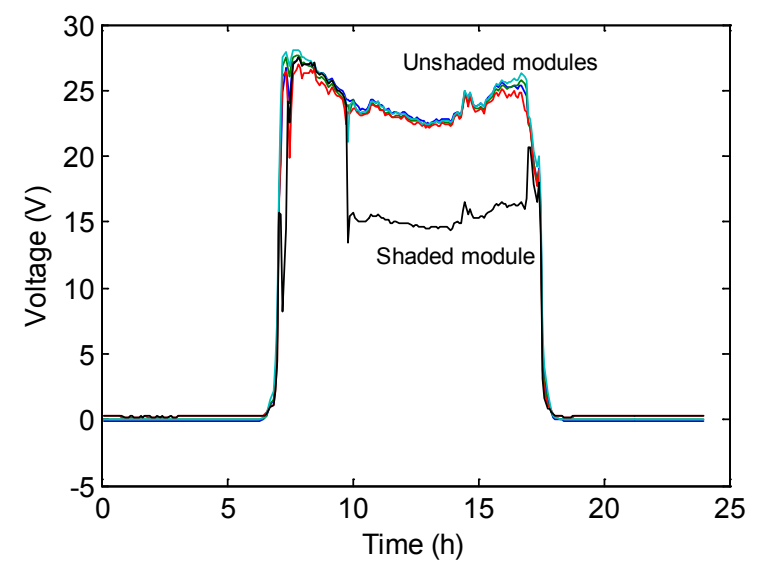

Fig. 3: Module voltages are shown for a typical day. One cell is completely shaded around 10 AM dropping that module's voltage by $1 / 3$. The voltage drop results from one of the three module bypass diodes turning on and conducting the entire system current around the shaded group of cells.

Half of the modules are chosen as candidates for shading. One cell per module is shaded with opaque masking tape in the amount of $10 \%, 16 \%, 20 \%, 24 \%, 31 \%, 35 \%$ or $39 \%$ of a cell's area. Twenty-five different cells were shaded in total at each of these shading levels to provide a distribution of the shading effect. Relative power output of the shaded group of cells is determined by the shaded module's output voltage relative to an un-shaded control module. Data is only considered from sunny days within the 3-week data collection interval, while irradiance is greater than $400 \mathrm{~W} / \mathrm{m}^{2}$.

A comparison of the effect of various cell shading percentages is shown in Fig. 4. As can be seen in this figure, the relative power output of the shaded group of cells decreases significantly when $25-40 \%$ of a single cell is shaded. Any shading coverage greater than $40 \%$ of one cell results in the total reduction of that 18-cell string's power output. This huge power loss illustrates a worstcase scenario in the disproportionate reduction of power from a small shadow. Shading half of one cell negates all the power produced by the 18 cells in that bypass diode group. Therefore, the reduction in power from shading half of one cell is equivalent to removing a cell active area 36 times the shadow's actual size. 


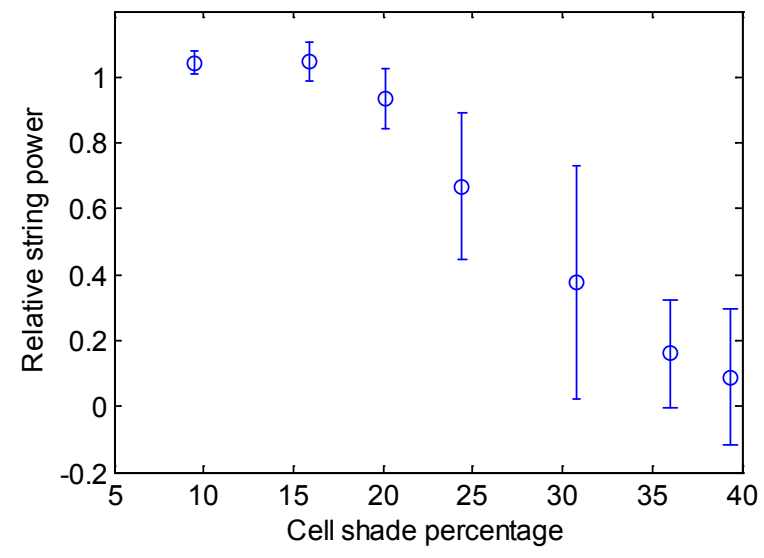

Fig. 4: Impact of single-cell shading on the output power of the 18-cell string. Shading greater than $40 \%$ of any single cell leads to total loss of power for the group of cells protected by that bypass diode. Error bars represent +/one standard deviation.

Very specific and distributed shading is required to achieve such a high multiplication in shading effect. The benefit of bypass diodes in shaded modules becomes clear when the cell becomes additionally shaded. Any further shading of the cell, or of any other cells in the same group yields no further reduction in module or system power. A useful measure of the relative impact of shading on a system is the Shade Impact Factor (SIF) [12] which is a relationship between the spatial extent of shade on a module or system, and its resulting power reduction. The shade impact factor can be represented by:

$$
S I F=\left[1-\frac{P_{\text {shade }}}{P_{\text {sys }}}\right] \frac{A_{\text {sys }}}{A_{\text {shade }}}
$$

where $P_{\text {sys }}$ and $A_{\text {sys }}$ are the nominal system power and area, $A_{\text {shade }}$ is the shaded area, and $P_{\text {shade }}$ is the power produced under shaded conditions. For the previously considered worst-case scenario of shade covering half of one cell, SIF $=36$ because this size of shadow causes a power reduction $36 \mathrm{x}$ greater than the relative size of the shadow would suggest. In systems where individual cell bypass diodes are present or a shadow projects uniformly on all cells, SIF $\approx 1$.

Fig. 4 also shows a relatively large distribution of output power for cells shaded near $30 \%$. One reason for the diversity in power levels can be attributed to differences between the shaded response of various cells. Previous experiments have shown that differences in the reverse bias characteristic of cells can lead to dissimilar shaded and hot-spot response of cells that have otherwise similar forward characteristics. $[13,14,15]$ Because of this variation in reverse characteristic, some cells are more susceptible to shade than others. In particular, Type A or high shunt resistance cells have a flat reverse bias characteristic [16] and as such are particularly susceptible to biasing to high negative voltages with small amounts of shade. If a Type A cell is shaded, it will dissipate more power within itself than a lower shunt resistance Type $B$ cell would. A Type A cell will also bias to a greater negative voltage than a Type $B$ cell for the same reverse current, and therefore has a lower shade tolerance before its group's bypass diode begins conducting.

A second contribution to the wide distribution of output power for cells shaded near $30 \%$ comes from differences in irradiance levels. Fig. 4 shows data for a variety of irradiance levels between $400 \mathrm{~W} / \mathrm{m}^{2}$ and $1100 \mathrm{~W} / \mathrm{m}^{2}$. When data is evaluated for different irradiance levels, it becomes clear that the same percentage of shade results in a greater shade impact factor at higher irradiance. This trend is shown in Fig. 5.

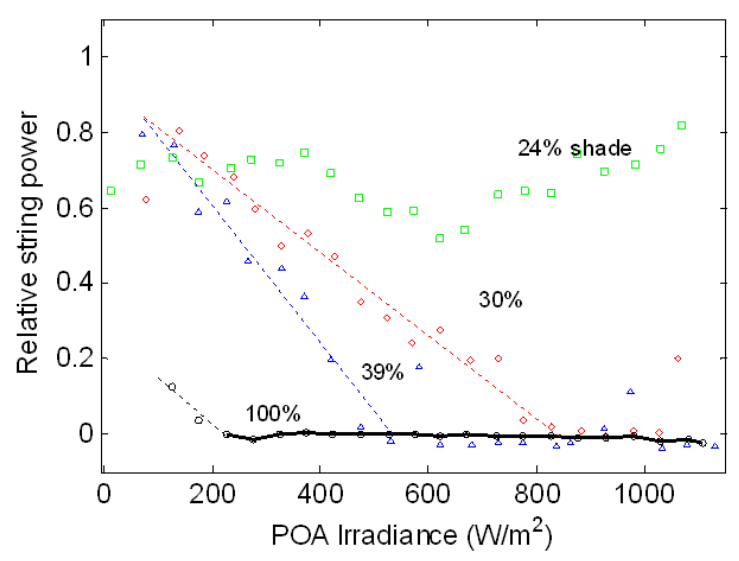

Fig. 5: Partially shaded power output for different plane-ofarray irradiances. Shaded impact on power output increases at higher irradiance as the system current increases.

All of the partially shaded cells yield similar power output at low irradiance. However, as irradiance and therefore the series string current is increased, power in the more highly shaded cells quickly drops. The power from a group of cells eventually reaches zero at high irradiance as the protecting bypass diode begins to conduct current. For the group of cells containing the $39 \%$ shaded cell, output power drops to zero at $>500 \mathrm{~W} / \mathrm{m}^{2}$ irradiance. The same is true of the $30 \%$ shaded cell group at $>800 \mathrm{~W} / \mathrm{m}^{2}$. For the $24 \%$ shaded cell group, the power never drops much even at high irradiance. The relative output power remains high for this partially shaded condition because the reverse bias power dissipated within the $24 \%$ shaded cell is not great enough to result in the bypass diode turning on. The voltage of the module does drop, meaning that the cell is reverse biased and dissipating power to some extent, just not enough to reduce the output power to zero. 


\section{Test \#2: Nearby shade obstructions}

A second type of shade was applied to the same array configuration. Two different opaque shading objects were placed near two of the modules in order to cast a shadow at different times of the day. A flat plate measuring $60 \mathrm{~cm}$ $x 60 \mathrm{~cm}$ was positioned $50 \mathrm{~cm}$ to the east of the last module in the array. The second shade obstruction is a 4 " diameter PVC pipe attached at the bottom right corner of another module in the array. The cylindrical obstruction extends above the bottom edge of the module by $35 \mathrm{~cm}$. The layout of the shade obstructions is shown in Fig. 6.

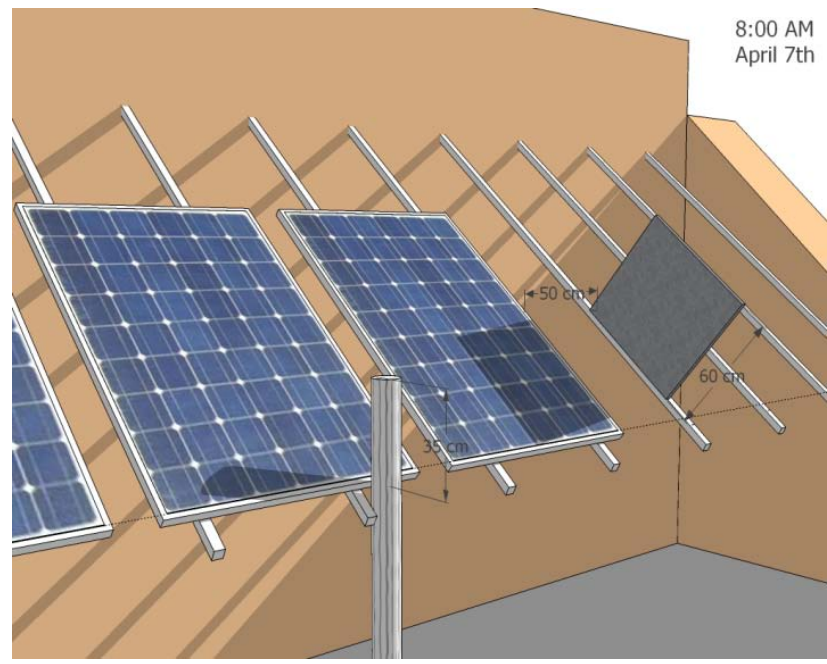

Fig. 6: Flat plate and pole shade obstructions installed near two modules in Test \#2. Shading simulation is shown here for 8:00 on April $7^{\text {th }}$.

Examples of the shadows cast by the two shade obstructions can also be seen in Fig. 6. The flat plate obstruction casts a rectangular shadow extending all the way across the module at its maximum extent. The cylindrical post casts a long, thin shadow that tracks across the module throughout the day. By monitoring the module voltages and recording the extent of the shadows, an estimate of the power lost due to shade and therefore the shade impact factor can be determined. The results for both the pole and the flat plate obstruction over a 2hour period beginning at 7:30 AM are shown in Fig. 7 .

It is clear from Fig. 7 that a small amount of shade e.g. from 2-3 partially shaded cells leads to a large SIF and a disproportionate loss in power. As the shadow of either the pole or the flat plate covers a greater portion of a module, the Shade Impact Factor (Eq. 1) decreases. In fact, the best fit line to the flat plate shading data follows SIF $\propto(\text { Shade } \%)^{-1}$. For a module that is covered by shade over $15-50 \%$ of its area, the Shade Impact Factor approaches SIF $=2$. A shadow that covered the entirety of one module would have the value SIF $=1$. The value SIF $=2$ has been adopted by the California Energy Commission as a constant shade penalty factor for its
Expected Performance Based Incentive program. [12] It would appear that this value is consistent with shade of moderate extent (15\%-50\%) covering parts of one or more modules in the array.

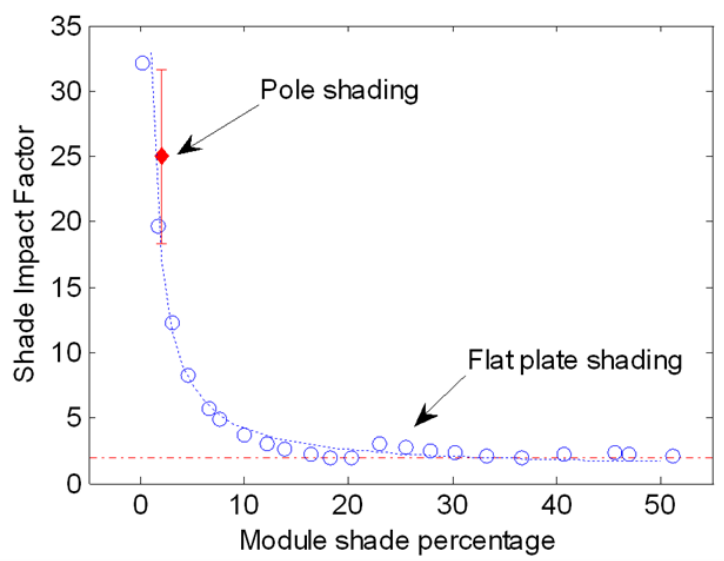

Fig. 7: Shade Impact Factor for a pole shadow $(\diamond)$ or flat plate shadow (o) falling on a single module. ("): Leastsquares fit to the data following $y=31.9 x^{-1} .(-\cdot)$ : Constant $S I F=2$ value .

\section{SITE SURVEY \& SHADE SIMULATION}

PV performance estimation becomes more accurate with the incorporation of data from a shading site survey. Present site survey devices provide information on the available solar resource based on the surrounding shade obstructions at the survey site. However, this calculation does not account for the partial shade conditions on different parts of the array. Following the method of Drif et al. [17] it is possible to take one site survey measurement and to predict what the shade extent would look like at any arbitrary point on the array. By calculating the spatial extent of the shadow on a PV array and using example Shade Impact Factor data from Fig. 7, an accurate time-ofday shadow derating for the particular installation can be determined.

Several site survey products are available that provide the azimuth angle and elevation angle from surrounding obstructions in graphical and tabular format. An example output taken from the Test \#2 experiment setup is shown in Fig. 8. If the $i$ shade vertex azimuth and elevation points $\psi_{o b}^{i}, \theta_{o b}^{i}$ are known along with the distance from the survey site to the ith shade obstruction $r_{o b}^{i}$, Cartesian coordinates for the shade points can be determined: $\left(x_{o b}^{i}, y_{o b}^{i}, z_{o b}^{i}\right)$ via coordinate transform. Here positive $x$ and $y$ are taken to be east and north, respectively. The $(0,0,0)$ origin coincides with where the site survey measurement was taken. 


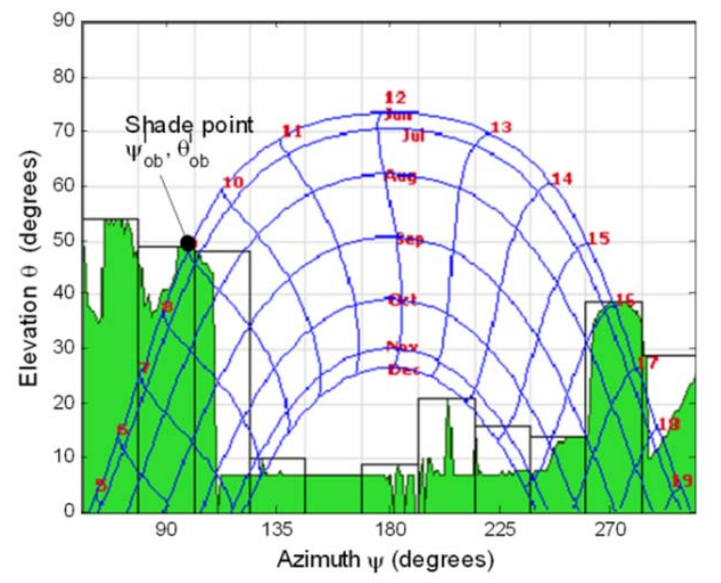

Fig. 8: Azimuth and elevation coordinates for a sample site survey. Green polygons represent the shading objects present in Test \#2. A sun path diagram displays the time of day when shading is apparent at the site survey location.

A set of $j$ coordinates for the photovoltaic system is also generated: $\left(x_{P V}^{j}, y_{P V}^{j}, z_{P V}^{j}\right)$ relative to the site survey location. The position of each shading point relative to each PV point can be determined by the following coordinate transforms: [17]

$$
\begin{gathered}
\psi^{i, j}=\tan ^{-1}\left(\frac{x_{o b}^{i}-x_{P V}^{j}}{y_{o b}^{i}-y_{P V}^{j}}\right) \\
\theta^{i, j}=\tan ^{-1}\left(\frac{z_{o b}^{i}-z_{P V}^{j}}{\sqrt{\left(x_{o b}^{i}-x_{P V}^{j}\right)^{2}+\left(y_{o b}^{i}-y_{P V}^{j}\right)^{2}}}\right)
\end{gathered}
$$

At any given point $j$ on the PV array, the azimuth $\psi^{i, j}$ and elevation $\theta^{i, j}$ of the surrounding shading obstructions are known. This provides a useful estimate of shade conditions at a given PV point and time of day if the solar azimuth $\psi_{\text {sun }}$ and elevation $\theta_{\text {sun }}$ are known. By comparing $\theta_{\text {sun }}$ with $\theta^{i, j}$ at a given azimuth, where $i$ is chosen such that $\psi^{i, j}=\psi_{\text {sun }}$, shade will be present at array vertex $j$ if $\theta_{\text {sun }}<\theta^{i, j}$.

A numerical simulation can be conducted where the shade present on the array is calculated for each time of day throughout the year. Depending on the spatial resolution desired in the simulation, the $j$ coordinates for the photovoltaic system may be chosen to match the vertices of each module, the vertices of each cell in each module, or any other value, limited only by the processor memory and speed. The $\psi^{i, j}$ and $\theta^{i, j}$ apparent shade vertices are calculated for each PV coordinate and compared with the sun's position at each time of day, providing a picture of shade on the PV system. For a single grid-tied PV string, the relative string power and shade impact factor of Fig. 4 and Fig. 7 can then be used to translate shade percentage into power reduction for the system. Multiple shaded vertices on a group of cells or module indicate that the bypass diodes for that group are conducting and reducing the system output power by an equivalent amount.

A comparison between experimental results from Test \#2 and the simulation method described here are shown in Fig. 9. This plot shows the relative reduction in power of a single module as shadow crosses it over one day. The simulation input is the site survey details shown in Fig. 8. The particular module being monitored is the last module in the array, visible to the right of Fig. 6 . Shade from the flat plate shade obstruction covers most of the module early in the morning, reducing power output between 7 and $10 \mathrm{AM}$. Shade from the pole obstruction is apparent on this module by $3 \mathrm{PM}$.

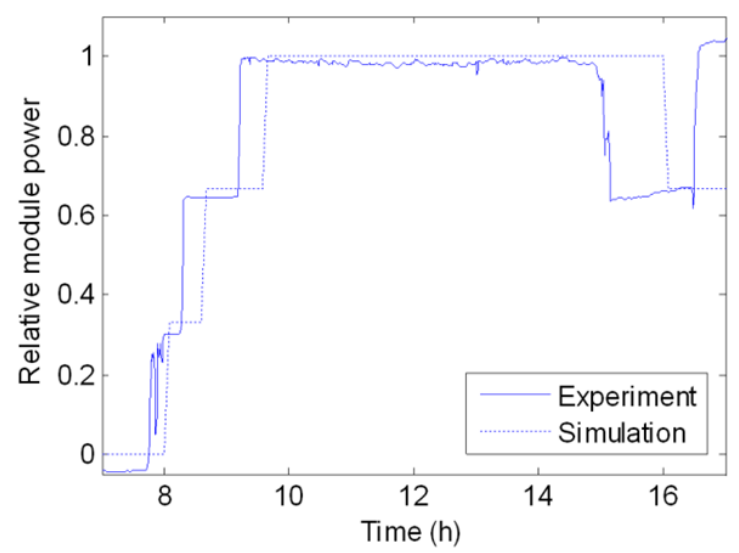

Fig. 9: Shaded module power relative to an unshaded control over a cloudless day. Simulation data comes from a site survey and shade simulation utilizing 150 PV array datapoints, 171 shade obstruction datapoints and 5 minute solar positions.

Some timing differences are visible between the experiment and simulation data. This discrepancy may partly be due to the low spatial resolution of the simulation - using on average one PV datapoint per cell - and partially due to the shade obstructions being so close to the array. The close shade obstructions result in much greater spatial error when the shade coordinates are translated to other PV locations. A more typical shade condition would have greater distance to the shade obstructions, which would likely translate to greater accuracy in the simulation.

\section{CONCLUSIONS}

Partial shading of PV installations has a disproportionate impact on power production. For a single-string grid-tied PV system, a shadow can represent a reduction in power over 30 times its physical size. In order to accurately predict the power lost due to shaded conditions, it is necessary to identify the bypass diode placement in the 
PV modules, as bypass diodes regulate the impact of shading on a particular module or group of cells. With an accurate description of the PV module layout, a single site survey can provide an estimate of shade conditions at one position, and geometric transforms can translate that shade description to any point in the PV array. This process can provide the basis for an accurate simulation of power reduction in a partially shaded PV system.

Future work on this project includes investigating the impact of shade on thin film modules, and their shade tolerance relative to crystalline silicon modules. Parallelstring PV systems will also be investigated and compared with the single-string results presented here.

\section{Acknowledgment}

This work was supported by the U.S. Department of Energy under Contract No. DOE-AC36-08G028308 with the National Renewable Energy Laboratory.

\section{REFERENCES}

[1] K. Kurokawa, "Realistic values of various parameters for PV system design”, Renewable Energy 15, 1998, pp. $157-164$

[2] U. Jahn, "Operational performance of grid-connected PV systems on buildings in Germany", Progress in Photovoltaics 12, 2004, pp. 441-448

[3] A. Woyte, J. Nijs, and R. Belmans, "Partial shadowing of PV arrays with different system configurations: literature review and field test results", Solar Energy 74, 2003, pp. 217-233

[4] N. Kaushika and N. Gautam, "Energy yield simulations of interconnected solar PV arrays", IEEE trans. energy conversion 18, 2003 pp.127-134

[5] H. Kawamura et al., "Simulations of I-V characteristics of a PV module with shaded PV cells", Solar energy materials \& solar cells 75, 2003 pp. 613-621

[6] R. Bruendlinger et al., "Maximum power point tracking performance under partially shaded PV array conditions", 21st European PV energy conference 4-8 Sept. 2006

[7] M. Garcia et al., "Partial shadowing, MPPT performance and inverter configurations: observations at tracking PV plants", Prog. Photovolt: Res. Appl. 16, 2008, pp. $529-536$

[8] N. Chaintreuil et al., "Effects of shadow on a grid connected PV system", 23rd European PV energy conference, 2008, p.3417
[9] J. Bishop, "Microplasma breakdown and hot-spots in silicon solar cells", Solar Cells 26, 1989, pp. 335-349

[10] G. Bhattacharya and C. Neogy, "Removal of the hotspot problem in photovoltaic modules and arrays", Solar Cells 31, 1991, pp. 1-12

[11] B. Marion, J. Rodriguez, J. Pruett, "Instrumentation for evaluating PV system performance losses from snow", ASES Solar 2009 Conference, May 2009

[12] California Energy Commission SB1 Guidelines 2008 pg. 56: http://www.energy.ca.gov/2008publications/CEC300-2008-007/CEC-300-2008-007-CMF.PDF

[13] E. Molenbroek, D. Waddington and K. Emery, "Hot spot susceptibility and testing of PV modules", 22nd IEEE Photovoltaic Specialists Conference, 1991, pp. 547-552

[14] W. Herrmann, W. Wiesner and W. Vaassen, "Hot spot investigations on PV modules-new concepts for a test standard and consequences for module design with respect to bypass diodes" 26th IEEE Photovoltaic Specialists Conference,1997, pp. 1129-1132

[15] M. Alonso-Garcia, J. Ruiz and F. Chenlo, "Experimental study of mismatch and shading effects in the IV characteristic of a photovoltaic module", Solar Energy Materials \& Solar Cells 90, 2006, pp. 329-340

[16] International Electrotechnical Commission (IEC) 61215, "Crystalline silicon terrestrial photovoltaic (PV) modules - design qualification and type approval", pp. 5564 (2005)

[17] M. Drif, P. Perez, J. Aguilera and J. Aguilar, "A new estimation method of irradiance on a partially shaded PV generator in grid-connected photovoltaic systems", Renewable Energy 33, 2008, pp. 2048-2056 


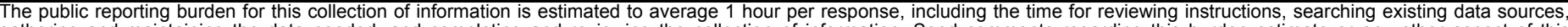

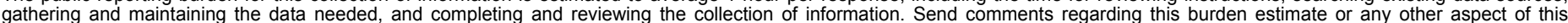

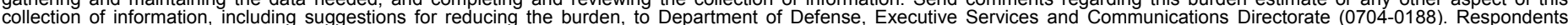

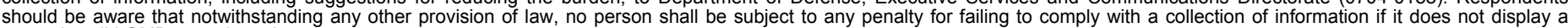

should be aware that notwithstanding

PLEASE DO NOT RETURN YOUR FORM TO THE ABOVE ORGANIZATION.

\section{REPORT DATE (DD-MM-YYYY) June 2009 \\ 2. REPORT TYPE \\ Conference Paper}

4. TITLE AND SUBTITLE

Partially Shaded Operation of a Grid-Tied PV System: Preprint
3. DATES COVERED (From - To) 7-12 June 2009

5a. CONTRACT NUMBER

DE-AC36-08-GO28308

5b. GRANT NUMBER

5c. PROGRAM ELEMENT NUMBER

5d. PROJECT NUMBER

NREL/CP-520-46001

5e. TASK NUMBER

PVB77602

5f. WORK UNIT NUMBER
7. PERFORMING ORGANIZATION NAME(S) AND ADDRESS(ES)

National Renewable Energy Laboratory

1617 Cole Blvd.

Golden, CO 80401-3393

\section{PERFORMING ORGANIZATION REPORT NUMBER \\ NREL/CP-520-46001}

9. SPONSORING/MONITORING AGENCY NAME(S) AND ADDRESS(ES)

\section{SPONSOR/MONITOR'S ACRONYM(S)} NREL

11. SPONSORING/MONITORING AGENCY REPORT NUMBER

12. DISTRIBUTION AVAILABILITY STATEMENT

National Technical Information Service

U.S. Department of Commerce

5285 Port Royal Road

Springfield, VA 22161

\section{SUPPLEMENTARY NOTES}

\section{ABSTRACT (Maximum 200 Words)}

Partial shading of a photovoltaic (PV) installation has a disproportionate impact on its power production. This paper presents background and experimental results from a single-string grid-tied PV system, operated under a variety of shading conditions. In this configuration, a shadow can represent a reduction in power over 30 times its physical size. Results are presented relating size and positions of shading to power reduction of the PV system. A simulation method is also described that provides an accurate description of shade based on a single site survey. This process can provide the basis for an accurate simulation of power reduction in a partially shaded PV system.

\section{SUBJECT TERMS}

PV; partially shading; grid-tied system; power reduction; crystalline silicon; module; simulation method; bypass diode;

\begin{tabular}{l}
\hline \begin{tabular}{l|l|l|}
\hline 16. SECURITY CLASSIFICATION OF: \\
$\begin{array}{l}\text { a. REPORT } \\
\text { Unclassified }\end{array}$ & $\begin{array}{c}\text { b. ABSTRACT } \\
\text { Unclassified }\end{array}$ & $\begin{array}{l}\text { c. THIS PAGE } \\
\text { Unclassified }\end{array}$ \\
& & \\
\hline
\end{tabular}
\end{tabular}

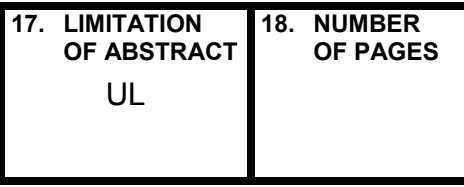

19a. NAME OF RESPONSIBLE PERSON

19b. TELEPHONE NUMBER (Include area code) 